\title{
Introduction to Theme Issue: Emerging Electronic Networks and Democratic Life
}

\author{
NICHOLAS W. JANKWOSKI and SLAVKO SPLICHAL
}

The European Institute of Communication and Culture (Euricom) and the University of Nijmegen are engaged in a long-term investigation into understanding the problems and possibilities of electronic networks in democratic life. The first of a series of seminars on this topic was held September 2001 in Piran, Slovenia. During this conference, 21 scholars from around Europe, Asia and New Zealand convened and presented papers related to a single overriding question: In what manner and to what degree can electronic networks contribute to a more informed and politically active citizenry?

Seven of the contributions to that Euricom Colloquium have been prepared for this theme issue of Communications: The European Journal of Communication. Another selection of papers from the Colloquium is being prepared for publication in the journal Javnost/The Public. Both of these issues provide a good overview of the scholarship presented in Piran.

This issue of Communications leads off with a study by Seija Ridell from the University of Tampere, Finland, in which the Web as a metaphor for physical space and terrain for social action is explored. Ridell's main concern is how the globally oriented Internet can be engaged for locally oriented purposes. One of the points she addresses is how locally established practices of public communication are manifested on the Internet.

Kees Brants from the University of Amsterdam, The Netherlands, considers whether political deliberation is possible in an electronic network environment. Using a typology of political web sites, he considers the nature of discourse present on three Dutch web sites. This study poses more problems than answers and raises the fundamental question as to whether the concept public sphere is suitable for this arena of political deliberation.

Martine van Selm, Nicholas Jankowski and Liza Tsaliki - all affiliated with the University of Nijmegen, The Netherlands - examine to 
what degree indicators of digital democracy are evident in discussions held on political party web sites and in the responses to an online survey held among participants in these discussions. Although minor differences were found in how the parties presented political information, more substantial differences were evident in the nature of the political discourse on the three web sites. These differences reflected the general political image of each respective party.

Anna Malina from the International Teledemocracy Centre at Napier University in Edinburgh, Scotland, considers the place of a digital community network in the process of community development ongoing in a housing estate in Edinburgh. This case study explores how definitions of community and the legacy of community development work in the United Kingdom have framed discourse about the civic worth of such digital community networks.

Kenneth Hacker from New Mexico State University poses a new term - network democracy - intended to describe the fusion of the concepts network society and digital democracy. Building on arguments from Manuel Castells regarding the so-called Fourth World where inequality, poverty and disempowerment reign, Hacker suggests a theoretical perspective that helps understand the potential for transforming the conditions associated with Castells' Fourth World.

Ann Macintosh, Anna Malina and Angus Whyte - all associated with the International Teledemocracy Centre (ITC) at Napier University in Edinburgh, Scotland - lay out the operational research program of what may be a unique institution in Europe. The ITC is engaged in developing a body of tools and techniques designed to facilitate use of electronic communication, particularly between the Scottish Parliament and citizens in the country. For example, forms of Internet voting are assessed and recommendations made for extended experimentation.

Finally, Christina Prell from Rensselaer Polytechnic Institute in Troy, New York, describes the early phases of engaging young people in a community network situated in this Upstate New York town. Some of the problems in introducing the technology to this age group are noted, as well as community responses to the possibilities of the technology. Part of a $\mathrm{PhD}$ dissertation project, Prell also sketches the theoretical perspectives guiding the study - social construction of technology and social worlds theory.

As mentioned at the beginning of this introduction, other events are scheduled to follow the Euricom Colloquium held last September. A sequel is being planned in October 2002 in Nijmegen, The Netherlands. Some 40 papers will be presented at this follow-up event. One of the objectives of the second Colloquium is to formulate a research agenda for collaborative investigations into the societal implications and impacts 
of electronic networks on democratic institutions and practices during the coming decade. Central to this objective is the need to develop an ongoing working group, including both young and established researchers, concerned with the enactment of this agenda through long-term exploration of electronic networks.

This is, in fact, the central task of what has come to be known as the Euricom Project. The second Colloquium will, like the first, result in theme issues of scholarly journals. A selection of this material will also be published in a new book series available from Hampton Press - Euricom Monographs. More information on these and other activities of the Euricom Project can be found at: http://baserv.uci.kun.nl/ jankow/Euricom.

Finally, we wish to thank the institutions that made the first event of this Euricom Project possible - the Universities of Ljubljana and Nijmegen, the Slovenian Ministry of Education, Science and Sports, and the Slovenian Ministry of Information Society. We especially wish to extend our gratitude to the scholars who contributed to this specific event and to the long-term scholarly endeavor at investigating the place of electronic networks in democratic life. 